\begin{tabular}{|c|c|c|}
\hline Case Reports in & \multicolumn{2}{|c|}{ Case Rep Gastroenterol 2015;9:215-220 } \\
\hline Gastroenterology & $\begin{array}{l}\text { DOI: } 10.1159 / 000437138 \\
\text { Publisned online: July } 8,2015\end{array}$ & $\begin{array}{l}\text { (c) } 2015 \text { S. Karger AG, Basel } \\
1662-0631 / 15 / 0092-0215 \$ 39.50 / 0 \\
\text { www.karger.com/crg }\end{array}$ \\
\hline & \multicolumn{2}{|c|}{$\begin{array}{l}\text { This is an Open Access article licensed under the terms of the Creative Commons } \\
\text { Attribution-NonCommercial } 3.0 \text { Unported license (CC BY-NC) (www.karger.com/OA- } \\
\text { license), applicable to the online version of the article only. Distribution permitted for non- } \\
\text { commercial purposes only. }\end{array}$} \\
\hline
\end{tabular}

\title{
Sustained Virological Response after 8-Week Treatment of Simeprevir with Peginterferon $\alpha-2 a$ plus Ribavirin in a Japanese Female with Hepatitis C Virus Genotype 1b and IL28B Minor Genotype
}

\author{
Tatsuo Kanda Masato Nakamura Reina Sasaki Shin Yasui \\ Shingo Nakamoto Yuki Haga Xia Jiang Shuang Wu \\ Akinobu Tawada Makoto Arai Fumio Imazeki Osamu Yokosuka \\ Department of Gastroenterology and Nephrology, Chiba University Graduate School of \\ Medicine, Chiba, Japan
}

\section{Key Words}

Hepatitis C virus - Simeprevir · Peginterferon - Ribavirin - Sustained virological response

\begin{abstract}
Direct-acting antivirals with or without peginterferon $\alpha$ (PEG-IFN $\alpha)$ plus ribavirin are now available for the treatment of hepatitis $\mathrm{C}$ virus (HCV) infection. Direct-acting antivirals are potent inhibitors of HCV replication, but some of them occasionally possess serious adverse events. We experienced a 64-year-old female with chronic HCV genotype $1 \mathrm{~b}$ infection who showed elevated alanine aminotransferase of $528 \mathrm{IU} / \mathrm{l}$ at week 9 after the commencement of treatment of simeprevir with PEG-IFN $\alpha$-2a plus ribavirin. However, she achieved sustained virological response at week 24 after the end of treatment. In Japan, we also have to treat elderly patients infected with HCV and/or advanced hepatic fibrosis. Until an effective interferon-free regimen is established, direct-acting antivirals with PEG-IFN plus ribavirin may still play a role in the treatment for certain patients. To avoid serious results from adverse events, careful attention and follow-up will be needed in the treatment course of simeprevir with PEG-IFN plus ribavirin for chronic HCV infection.

(c) 2015 S. Karger AG, Basel
\end{abstract}

KARGER 125/s $\quad \begin{aligned} & \text { Tatsuo Kanda, MD } \\ & \text { Department of Gastroenterology and Nephrology } \\ & \text { Chiba University Graduate School of Medicine } \\ & \text { 1-8-1 Inohana, Chuo-ku, Chiba 260-8670 (Japan) } \\ & \text { E-Mail kandat-cib@umin.ac.jp }\end{aligned}$


Kanda et al.: SVR after 8-Week Treatment of Simeprevir with PEG-IFN $\alpha$-2a plus Ribavirin in a Japanese Female with HCV Genotype 1b and IL28B Minor Genotype

\section{Introduction}

Hepatitis $\mathrm{C}$ virus (HCV) infection causes acute hepatitis, chronic hepatitis, cirrhosis and hepatocellular carcinoma [1,2]. The number of liver transplantations associated with HCV is also growing in Japan [3]. In Japan, the rates of HCV genotypes $1 \mathrm{~b}, 2 \mathrm{a}$ and $2 \mathrm{~b}$ are approximately 70, 20 and 10\%, respectively, with genotype 1 a being very rare $[4,5]$.

Since the end of 2013, the HCV NS3/4A inhibitor simeprevir, together with peginterferon (PEG-IFN) plus ribavirin, has been available in Japan for the treatment of HCV genotype 1 patients [6]. In treatment-naïve patients, previous treatment relapsers and null responders, respectively, this treatment results in 89-92, 96-100 and 36-39\% sustained virological response (SVR). Thus, simeprevir is a strong protease inhibitor for HCV NS3/4A.

However, it is known that hyperbilirubinemia is one of the common side effects of simeprevir. Recently, Stine et al. [7] reported that 2 patients developed marked hyperbilirubinemia out of proportion to their aminotransferase levels, despite clearance of HCV RNA. In the present report, we show a case re-treated by simeprevir with PEG-IFN $\alpha$-2a plus ribavirin who experienced elevated alanine aminotransferase (ALT) without hyperbilirubinemia. Despite stopping her treatment at 8 weeks, she achieved SVR.

To avoid serious results from adverse events, careful follow-up should be performed in the clinical use of protease inhibitors for HCV-infected patients, even if they have no advanced fibrosis. In addition, even after the introduction of interferon-free regimens, which have strong effects for the eradication of HCV RNA, careful follow-up of patients may still be needed in daily clinical practice.

\section{Case Report}

A 64-year-old Japanese woman was infected with HCV genotype 1b, 7.4 log IU/ml of viral load, and TG of IL28B rs8099917. In another hospital 8 years earlier, she was diagnosed with chronic HCV infection, liver biopsy was performed, and mild portal fibrosis (F1) and mild activity of inflammation (A1) were observed. She was subsequently treated with PEG-IFN $\alpha$-2b plus ribavirin for 72 weeks, but she relapsed in spite of being a late virological responder [5].

The patient's weight, height and body mass index were $46 \mathrm{~kg}, 1.55 \mathrm{~m}$ and $18.9 \mathrm{~kg} / \mathrm{m}^{2}$, respectively. Although she had undergone surgery for tongue cancer 15 years before, she looked healthy and was taking no medications for other diseases. Additional laboratory data were aspartate aminotransferase (AST) 24 IU/l, ALT 21 IU/l, $\gamma$-glutamyltransferase (G-GTP) $23 \mathrm{IU} / \mathrm{l}$, total bilirubin $0.8 \mathrm{mg} / \mathrm{dl}$, total cholesterol $236 \mathrm{mg} / \mathrm{dl}$, $\alpha$-fetoprotein $2.5 \mathrm{ng} / \mathrm{ml}$, prothrombin time $123 \%$, hemoglobin $14.0 \mathrm{~g} / \mathrm{dl}$ and platelet count $16.5 \times 10^{4} / \mathrm{mm}^{3}$. She was classified as having Child-Turcotte-Pugh class A. Ultrasonography showed no findings of hepatic mass, cirrhosis or splenomegaly. Transient elastography (Fibroscan) indicated $4.4 \mathrm{kPa}$, showing that she had no advanced liver disease.

As she was a previous treatment relapser despite IL28B of minor genotype, she was re-treated with simeprevir $100 \mathrm{mg}$ daily with PEG-IFN $\alpha-2 \mathrm{a} 180 \mu \mathrm{g}$ weekly and ribavirin $400 \mathrm{mg}$ daily. Rapid virological response, defined as undetectable HCV RNA at week 4, was achieved. At week 7, AST and ALT levels were within normal limits (22 and 12 IU/l, respectively). Although HCV RNA was undetectable at week 8, AST and ALT levels were mildly elevated (83 and $68 \mathrm{IU} / \mathrm{l}$, respectively). At week 9, she complained of fatigue and appetite loss, and her laboratory data showed hepatic injury (AST 506 IU/l, ALT 528 IU/l, G-GTP 52 IU/l, total bilirubin $1.2 \mathrm{mg} / \mathrm{dl}$, prothrombin time $126 \%$, hemoglobin $12.1 \mathrm{~g} / \mathrm{dl}$ and platelet count 
Kanda et al.: SVR after 8-Week Treatment of Simeprevir with PEG-IFN $\alpha$-2a plus Ribavirin in a Japanese Female with HCV Genotype 1b and IL28B Minor Genotype

$8.6 \times 10^{4} / \mathrm{mm}^{3}$ ) despite HCV RNA being undetectable. Most hepatitis viral markers and autoantibodies were negative (table 1 ).

Ultrasonography showed no evidence of atrophic liver or presence of ascites. The treatment with simeprevir $100 \mathrm{mg}$ daily with PEG-IFN $\alpha$-2a $180 \mu \mathrm{g}$ weekly plus ribavirin $400 \mathrm{mg}$ daily was immediately stopped, and stronger neo-minophagen C $100 \mathrm{ml}$ was used daily for 2 weeks to lower the ALT level. Loxoprofen sodium hydrate (60 mg for single use) and domperidone (10 $\mathrm{mg}$ for single use) used for interferon-related fever and appetite loss, respectively, were also ceased immediately. Her symptoms disappeared at week 2. ALT levels were 24 and $11 \mathrm{IU} / \mathrm{l}$, respectively, at week 4 and 12 after the end of treatment. At week 24 after the end of treatment, HCV RNA was undetectable (AST $20 \mathrm{IU} / \mathrm{l}$, ALT $12 \mathrm{IU} / \mathrm{l}$ ). Thus, although her treatment duration was only 8 weeks, she achieved SVR. During and after the treatment, hyperbilirubinemia was not observed (maximum total bilirubin $1.2 \mathrm{mg} / \mathrm{dl}$ ) (fig. 1).

Drug lymphocyte stimulation testing was performed, but the result was negative for simeprevir, ribavirin, loxoprofen sodium hydrate and domperidone [8]. Loxoprofen sodium hydrate and domperidone as well as ribavirin had been used in the previous treatment 8 years earlier. As drug toxicity by self-medication was also excluded, we diagnosed her as drug-induced liver injury by simeprevir with PEG-IFN $\alpha$-2a plus ribavirin.

\section{Discussion}

In the current report we presented a 64-year-old HCV-infected patient who was a previous treatment relapser with IL28B minor genotype. Despite 8-week treatment of simeprevir with PEG-IFN $\alpha$-2a plus ribavirin, she achieved SVR at 24 weeks after the end of treatment, providing support for the strong effects of simeprevir on HCV replication [6]. Our case also points out the possibility of the combination of simeprevir with PEG-IFN $\alpha$-2a plus ribavirin leading to liver injury without hyperbilirubinemia, as liver dysfunction improved immediately after stopping this treatment and other causes were excluded, despite there being no overt signs of drug-induced injury, such as eosinophilia. According to the patient's decision, we did not perform a liver biopsy.

During the treatment of PEG-IFN $\alpha$-2a plus ribavirin, despite HCV RNA negativity, a transient elevation in ALT levels was observed, although the ALT levels were $<200 \mathrm{IU} / \mathrm{l}$ in most reports [9]. Acute exacerbation with elevation of ALT levels was occasionally observed during the course of chronic hepatitis C, but these were improved in most cases if SVR was achieved by antiviral treatment. It is also known that HCV is a rare cause of acute liver failure [10].

In Japan, the HCV NS3/4A inhibitor telaprevir with PEG-IFN $\alpha$-2b plus ribavirin was approved in 2011 and in 2014 for HCV genotype 1 and 2 infection, respectively. Despite adverse events including dermatological side effects, telaprevir improved SVR rates in HCVinfected patients. One of the second-wave first-generation HCV NS3/4A inhibitors, simeprevir, together with PEG-IFN plus ribavirin, was also approved in 2013 for HCV genotype 1 infection in Japan. Compared to telaprevir, the adverse events of simeprevir with PEG-IFN plus ribavirin have become less. It has been reported that they are fairly similar to those of PEG-IFN plus ribavirin therapy, although hyperbilirubinemia without ALT elevation is occasionally observed.

In general, a mild, isolated and reversible increase in serum bilirubin was reported in patients treated with simeprevir, and bilirubin returned to baseline levels promptly after patients had completed the simeprevir regimen [6]. Hyperbilirubinemia was pronounced 
Kanda et al.: SVR after 8-Week Treatment of Simeprevir with PEG-IFN $\alpha$-2a plus Ribavirin in a Japanese Female with HCV Genotype 1b and IL28B Minor Genotype

with simeprevir $150 \mathrm{mg}$ daily [6], although we used simeprevir $100 \mathrm{mg}$ daily in Japan. Fried et al. [6] reported that there were no concomitant increases in serum ALT or alkaline phosphatase associated with bilirubin elevations in the PILLAR study.

In the present report, despite a strong antiviral effect of simeprevir, we observed liver injury during the simeprevir with PEG-IFN $\alpha$-2a plus ribavirin treatment, supporting a previous report that simeprevir may cause liver injury in patients with cirrhosis, leading to hepatic decompensation [8]. In our case, drug-induced liver injury caused by PEG-IFN $\alpha-2 \mathrm{a}$ could not be completely ruled out, although the previous use of PEG-IFN $\alpha-2 b$ had not caused liver injury.

In conclusion, to avoid serious results from adverse events, careful attention and followup are necessary in the clinical use of protease inhibitors for HCV-infected patients, and especially for those with advanced hepatic fibrosis. Until newer, safer, direct-acting antivirals against HCV, including HCV NS3/4A inhibitors, are introduced, we need to pay strict attention to these matters in the use of direct-acting antivirals against HCV.

\section{Acknowledgements}

The authors thank all medical staff at Chiba University Hospital for patient care.

\section{Disclosure Statement}

Tatsuo Kanda received lecture fees from Chugai Pharmaceutical, MSD, Tanabe-Mitsubishi, Ajinomoto, Bristol-Myers Squibb, Daiichi-Sankyo, Janssen Pharmaceutical and GlaxoSmithKline. Makoto Arai received lecture fees from Chugai Pharmaceutical, Eisai, AstraZeneca, Daiichi Sankyo and Tsumura. Osamu Yokosuka received grant support from Chugai Pharmaceutical, Bayer, MSD, Daiichi-Sankyo, Tanabe-Mitsubishi, Bristol-Myers Squibb, Taiho Pharmaceutical and Gilead Sciences. The other authors declare that they have no conflict of interests regarding the publication of this paper.

\section{References}

1 Di Bisceglie AM: Hepatitis C and hepatocellular carcinoma. Hepatology 1997;26(3 suppl 1):34S-38S.

2 Saito I, Miyamura T, Ohbayashi A, Harada H, Katayama T, Kikuchi S, Watanabe Y, Koi S, Onji M, Ohta Y: Hepatitis $C$ virus infection is associated with the development of hepatocellular carcinoma. Proc Natl Acad Sci USA 1990;87:6547-6549.

-3 Akamatsu N, Sugawara Y: Living-donor liver transplantation and hepatitis C. HPB Surg 2013;2013:985972.

-4 Wu S, Kanda T, Nakamoto S, Miyamura T, Nakatani SM, Ono SK, Takahashi-Nakaguchi A, Gonoi T, Yokosuka 0 : Prevalence of hepatitis $C$ virus subgenotypes $1 \mathrm{a}$ and $1 \mathrm{~b}$ in Japanese patients: ultra-deep sequencing analysis of HCV NS5B genotype-specific region. PLoS One 2013;8:e73615.

5 Kanda T, Imazeki F, Yokosuka O: New antiviral therapies for chronic hepatitis C. Hepatol Int 2010;4:548561.

6 Fried MW, Buti M, Dore GJ, Flisiak R, Ferenci P, Jacobson I, Marcellin P, Manns M, Nikitin I, Poordad F, Sherman M, Zeuzem S, Scott J, Gilles L, Lenz O, Peeters M, Sekar V, De Smedt G, Beumont-Mauviel M: Once-daily simeprevir (TMC435) with pegylated interferon and ribavirin in treatment-naïve genotype 1 hepatitis C: the randomized PILLAR study. Hepatology 2013;58:1918-1929.

7 Stine JG, Intagliata N, Shah NL, Argo CK, Caldwell SH, Lewis JH, Northup PG: Hepatic decompensation likely attributable to simeprevir in patients with advanced cirrhosis. Dig Dis Sci 2014;60:1031-1035.

-8 Suzuki Y, Miwa S, Shirai M, Ohba H, Murakami M, Fujita K, Suda T, Nakamura H, Hayakawa H, Chida K: Drug lymphocyte stimulation test in the diagnosis of adverse reactions to antituberculosis drugs. Chest 2008;134: 1027-1032. 
Kanda et al.: SVR after 8-Week Treatment of Simeprevir with PEG-IFN $\alpha$-2a plus Ribavirin in a Japanese Female with HCV Genotype 1b and IL28B Minor Genotype

-9 Nakamura M, Kanda T, Miyamura T, Wu S, Nakamoto S, Yokosuka O: Alanine aminotransferase elevation during peginterferon alpha-2a or alpha-2b plus ribavirin treatment. Int J Med Sci 2013;10:1015-1021.

10 Kanda T, Yokosuka O, Imazeki F, Saisho H: Acute hepatitis C virus infection, 1986-2001: a rare cause of fulminant hepatitis in Chiba, Japan. Hepatogastroenterology 2004;51:556-558.

Table 1. Laboratory findings at week 9

\begin{tabular}{llllll}
\hline Item & Value & Item & Value & Item & Value \\
\hline AST & $506 \mathrm{IU} / \mathrm{l}$ & WBC & $1,800 / \mathrm{mm}^{3}$ & HBsAg & negative \\
ALT & $528 \mathrm{IU} / \mathrm{l}$ & RBC & $402 \times 10^{4} / \mathrm{mm}^{3}$ & HCV RNA & negative \\
LDH & $476 \mathrm{IU} / \mathrm{l}$ & Hemoglobin & $12.1 \mathrm{~g} / \mathrm{dl}$ & IgA anti-HEV & negative \\
ALP & $363 \mathrm{IU} / \mathrm{l}$ & Hematocrit & $35.6 \%$ & IgM anti-HHV6 & negative \\
G-GTP & $52 \mathrm{IU} / \mathrm{l}$ & Platelets & $8.6 \times 10^{4} / \mathrm{mm}^{3}$ & IgM anti-EBVVCA & negative \\
TP & $7.3 \mathrm{~g} / \mathrm{dl}$ & Neutrophils & $52.9 \%$ & IgM anti-CMV & negative \\
Albumin & $4.2 \mathrm{~g} / \mathrm{dl}$ & Eosinophils & $1.1 \%$ & IgM anti-HSV & negative \\
UA & $4.2 \mathrm{mg} / \mathrm{dl}$ & Basophils & $0.0 \%$ & IgM anti-VZV & negative \\
BUN & $12 \mathrm{mg} / \mathrm{dl}$ & Monocytes & $8.5 \%$ & ANA & negative \\
Creatinine & $0.56 \mathrm{mg} / \mathrm{dl}$ & Lymphocytes & $37.5 \%$ & ASMA & negative \\
T.Bil & $1.2 \mathrm{mg} / \mathrm{dl}$ & PT & $126 \%$ & AMA & negative \\
D.Bil & $0.3 \mathrm{mg} / \mathrm{dl}$ & INR & 0.91 & LKM1 & negative \\
T.CHO & $177 \mathrm{mg} / \mathrm{dl}$ & AFP & $3.4 \mathrm{ng} / \mathrm{ml}$ & TSH & $1.688 \mathrm{mIU} / \mathrm{ml}$ \\
TG & $151 \mathrm{mg} / \mathrm{dl}$ & PIVKA-II & $18 \mathrm{mAU} / \mathrm{ml}$ & Free T3 & $2.66 \mathrm{pg} / \mathrm{ml}$ \\
Glucose & $111 \mathrm{mg} / \mathrm{dl}$ & KL-6 & $259 \mathrm{U} / \mathrm{ml}$ & Free T4 & 1.13 ng/dl \\
CRP & $0.0 \mathrm{mg} / \mathrm{dl}$ & IgM anti-HAV & $<0.40$ & & \\
ESR & $21 \mathrm{~mm} / \mathrm{h}$ & IgM anti-HBc & $<0.05$ & & \\
\hline
\end{tabular}

$\mathrm{AFP}=\alpha$-Fetoprotein; ALP = alkaline phosphatase; AMA = anti-mitochondrial antibody; ANA = anti-nuclear antibody; ASMA = antismooth muscle antibody; BUN = blood urea nitrogen; CRP = C-reactive protein; D.Bil = direct bilirubin; ESR = erythrocyte sedimentation rate; INR = international normalized ratio; KL-6 = sialylated carbohydrate antigen KL-6; LDH = lactate dehydrogenase; LKM1 = liver kidney microsomal type 1 antibody; PIVKA-II = protein induced by vitamin K absence or antagonists-II; PT = prothrombin time; $\mathrm{RBC}=$ red blood cell count; $\mathrm{T} 3=$ triiodothyronine; $\mathrm{T} 4=$ thyroxine; $\mathrm{T}$. Bil $=$ total bilirubin; $\mathrm{T} . \mathrm{CHO}=$ total cholesterol; $\mathrm{TG}=$ triglyceride; $\mathrm{TP}=$ total protein; $\mathrm{TSH}=$ thyroid-stimulating hormone; $\mathrm{UA}=$ uric acid; $\mathrm{WBC}=$ white blood cell count. 
Case Reports in
Gastroenterology

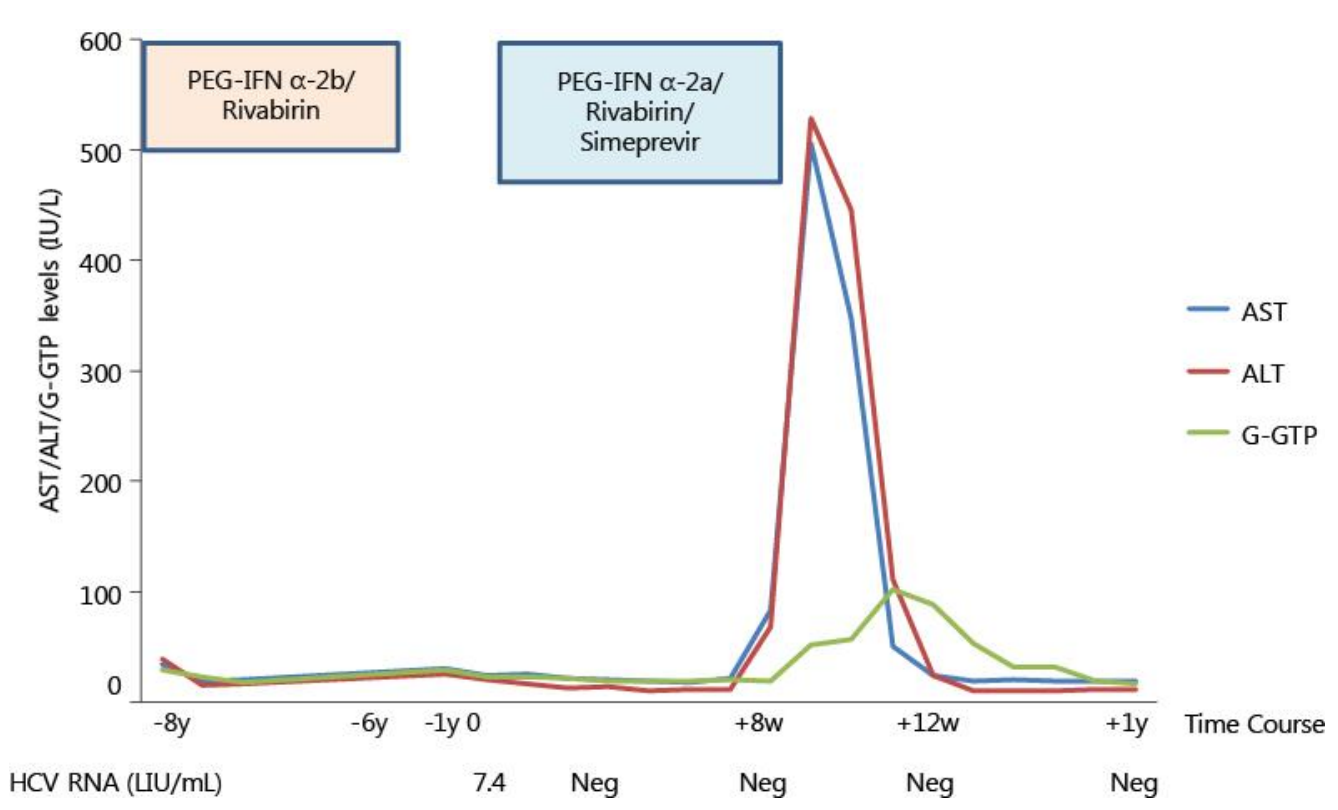

Fig. 1. Clinical course. The patient improved after stopping treatment of simeprevir with PEG-IFN $\alpha-2 a$ plus ribavirin. $\mathrm{y}=$ Years; $\mathrm{w}=$ weeks; $\mathrm{LIU} / \mathrm{mL}=\log \mathrm{IU} / \mathrm{ml} ; \mathrm{Neg}=$ negative.

Kanda et al.: SVR after 8-Week Treatment of Simeprevir with PEG-IFN $\alpha$-2a plus Ribavirin in a Japanese Female with HCV Genotype 1b and IL28B Minor Genotype 